\title{
Optimization of Ethanol Concentration and Time for Flavonoid Extraction of Melinjo Peel
}

\author{
Sucipto $^{1,2^{*}}$, Ismi Fadilla Ainur Husna ${ }^{1}$, Sri Kumalaningsih ${ }^{1}$ \\ ${ }^{1}$ Department of Agro-industrial Technology, Faculty of Agricultural Technology Universitas Brawijaya, Malang, \\ Indonesia \\ ${ }^{2}$ Halal-Qualified Industry Development, Faculty of Agricultural Technology Universitas Brawijaya Malang, Indonesia \\ *Corresponding author. Email:ciptotip@ub.ac.id
}

\begin{abstract}
The peel of melinjo (Gnetum gnemon) has potential as an anti-hyperuricemia. The content of flavonoids in the melinjo peel can inhibit the xanthine oxidase enzyme as a catalyst for the formation of uric acid compounds. The purpose of this study was to obtain the optimum extraction time and ethanol concentration for the extraction of flavonoids from the green melinjo peel using the maceration technique with heating and stirring. This research used response surface methodology (RSM) and central composite design (CCD). Factor 1 was the extraction time (X1) with a lower limit of 60 minutes and an upper limit of 120 minutes, and factor 2 was the ethanol concentration (X2) with a lower limit of $30 \%$ and an upper limit of $70 \%$. The responses were tested for a total of flavonoid, yield, and water content. The results showed that the optimum conditions were 5.11 minutes and $70 \%$ for the ethanol concentration. Verifying the optimum conditions, obtained melinjo peel extract had a total flavonoid $5.255 \mathrm{mg} \mathrm{QE} / \mathrm{g}$, moisture content of 5.766\%, and a yield of 33.657\%. The deviations from the program prediction results were $3.47 \%, 4.63 \%$, and $0.55 \%$, respectively.
\end{abstract}

Keywords: Anti-hyperuricemia, Extraction, Flavonoids, Melinjo Peel

\section{INTRODUCTION}

Melinjo (Gnetum gnemon) is a species of tree-shaped open seed plant (Gymnospermae) from Peninsular Malaysia. Distribution from Assam-India to the Fiji Islands [1]. All parts of the plant are used from stems, leaves, flowers, and seeds. Melinjo peel contains flavonoids that have the potential as gout herbs [2], but their use is still limited.

Gout is caused accumulation of monosodium urate crystals in the joints due to high uric acid levels in the body, so the joints are swollen, hot, and stiff [3]. Some research plants as anti-gout. Starfruit, bay leaf, black cumin seeds, galangal, cinnamon, turmeric, celery, leek, parsley, molokhia, S. orientalis, etc. [3-8]. Overcoming gout can be done by inhibiting the enzyme xanthine oxidase as a catalyst for the formation of uric acid compounds [9]. Several researchers have identified xanthine oxidase enzyme inhibitory activity in melinjo peel extract. Wulandari et al. [2] compared the inhibitory power of the xanthine oxidase enzyme in $70 \%$ ethanol extract of melinjo peel relative to allopurinol, where the highest power was in young melinjo peel extract at a concentration of $100 \mathrm{ppm}$ equivalent to allopurinol with a concentration of $19.9 \mathrm{ppm}$. Puspita et al. [10] identified the anti-hyperuricemic potential of $70 \%$ ethanol extract of melinjo peel, at $450 \mathrm{mg} / \mathrm{kg}$ web basic (wb) and 900 $\mathrm{mg} / \mathrm{kg}$ wb it was more effective in reducing uric acid levels than allopurinol at $90 \mathrm{mg} / \mathrm{kg}$ wb.

The flavonoids in melinjo peel inhibit hyper uric acid. Inhibition occurs due to the similarity of flavonoid structure with xanthine oxidase substrate, namely xanthine [2]. Green melinjo skin with the highest flavonoid was chosen compared to yellow and red skin [11]. 
Extraction of flavonoids uses maceration with heating and stirring. The heating process increases the extraction of insoluble compounds at room temperature [12]. Stirring makes the extraction more effective because it does not reduce the activity of moving the active substance [13]. The longer the extraction, the more material contact with the solvent affects the yield of the extract. The efficiency of the extraction process depends on timeliness [14]. The solvent must be in accordance with the solubility of the active component. Generally, flavonoids in plants are water-soluble glycosides to be extracted with hydro alcohol [15]. Ethanol is straightchain alcohol that is non-toxic and safe for consumption in herbal products. The concentration of solvent affects the strength of the withdrawal of the active compound [16].

Response surface method (RSM) is a multiresponse optimization method when the response is influenced by several variables [17]. The linear, quadratic, and interaction effects of independent variables during extraction can be determined using the Central Composite Design (CCD) [18]. The application of RSM for optimization of flavonoid extraction conditions has high accuracy. Liu et al. [19] optimized the extraction conditions for total flavonoids from Sculletaria baicalensis Georgi with the most optimal conditions being the extraction time of 2.12 hours, ethanol concentration of $52.98 \%$, extraction temperature of $62.46^{\circ} \mathrm{C}$, and a solution-solid ratio $(\mathrm{ml} / \mathrm{g})$ of 35.23 . Wu et al. [20] optimized the flavonoid extraction from basil with the best yield at extraction time of 2.06 hours, ethanol concentration $77.63 \%$, solution-solid ratio $(\mathrm{mL} / \mathrm{g})$ 29.72, and temperature $79.74^{\circ} \mathrm{C}$. Azahar et al. [18], optimized the extraction for phenolics and flavonoids from Curcuma Zedoaria leaves with an extraction time of 92 minutes, ethanol concentration of $90 \%$, and temperature of $75^{\circ} \mathrm{C}$. The purpose of this study was to optimize the extraction time and ethanol concentration for the extraction of flavonoids from melinjo peel.

\section{MATERIALS AND METHODS}

\subsection{Material and Equipment}

The production of melinjo peel extract uses the following tools: grinder, spatula, analytical balance, funnel, measuring cup, beaker, hotplate, magnetic stirrer, thermometer, baking sheet, oven, petri dish, vacuum oven, desiccator, and vacuum rotary evaporator. The analyzer consists of a UV-Vis spectrophotometer, cuvette, vortex, test tube, pipette, measuring flask, bulb, and measuring pipette,

Research materials include green melinjo skin, aquades, $96 \%$ ethanol, filter paper, filter cloth, aluminum foil. The extract drying ingredient is maltodextrin. Analytical materials include quercetin, $\mathrm{AlCl}_{3}, \mathrm{NaNO}_{2}$, and $\mathrm{NaOH}$.

\subsection{Experimental Set-up}

The research was conducted using response surface methodology (RSM) and central composite design (CCD). The independent variables were extraction time (X1) with a lower limit of 60 minutes and an upper limit of 120 minutes. The ethanol concentration (X2) with a lower limit of $30 \%$ and an upper limit of $70 \%$. Response variables were total flavonoids, water content, and yield. The optimal equation model was obtained by DesignExpert program DX 7.1.5 .

Extraction of melinjo peel using an ingredient-solvent ratio of $1: 30$, with $5 \mathrm{~g}$ of simplicial. The maceration method is accompanied by heating at $50^{\circ} \mathrm{C}$ and stirring at $200 \mathrm{rpm}$. The extract was concentrated with a vacuum rotary evaporator at a temperature of $50-55^{\circ} \mathrm{C}$ according to the ethanol concentration. The evaporated viscous extract was dissolved with $15 \%$ maltodextrin then dried in a vacuum oven at $55^{\circ} \mathrm{C}$ for 2 hours.

\subsection{Parameter Measurement}

\subsubsection{Total Flavonoid Analysis}

The total flavonoids (TF) of melinjo peel extract were tested by UV-Vis Spectroscopy based on Cahyanta [21]. The absorbance of the solution was measured at a wavelength of $328 \mathrm{~nm}$.

$$
\mathrm{TF}=\frac{\text { quercetin equivalence }\left(\frac{m g}{l}\right) \times \text { vol sample }(l) \times F P}{\text { sample mass }(g)} . .
$$

Where: TP is the dilution factor

\subsubsection{Yield Analysis}

Analysis the yield of melinjo peel extract based on Sa'adah and Henny [12]. The yield was calculated from the dry extract with the following calculations:

$$
\text { Yield }=\frac{\text { thick extract weight }(g)}{\text { initial simplicia weight }(g)} \times 100 \% \text {. }
$$




\subsubsection{Water Content Analysis}

Analysis of water content using the oven method [22] with the calculation:

Water content $(\%)=\frac{W}{W 1} \times 100 \%$

Where: $\mathrm{W}$ is the weight of the sample before drying, W1 is the weight loss after drying

\section{RESULT AND DISCUSSION}

\subsection{Total Flavonoids}

Optimization of extraction time and ethanol concentration to obtain melinjo peel extract powder which has maximum flavonoids. The independent variables of this study were the extraction time (X1) with a lower limit of 60 minutes and an upper limit of 120 minutes, and ethanol concentration (X2) with a lower limit of $30 \%$ and an upper limit of $70 \%$. This preliminary study obtained that extraction time was 90 minutes and the ethanol concentration $50 \%$. The responses are total flavonoid (Y1), water content (Y2), and yield (Y3). The analysis results of relationship variables and responses are presented in Table 1.

Based on the total response analysis of flavonoids, the following is a polynomial regression equation.

$\mathrm{Y} 1=1.3343+0.073736 \mathrm{X} 1-3.50431 \mathrm{E}-003 \mathrm{X} 2+$ 3.23333E-004X1*X2 - 4.96375E-004X12 - 1.41219E$004 \times 2^{2}$
Where: $\mathrm{Y} 1$ = Total flavonoids; A; X1 = Extraction time; $\mathrm{B} ; \mathrm{X} 2$ = Ethanol concentration

The effect of the extraction time and ethanol concentration on total flavonoid is shown in Figure 1.

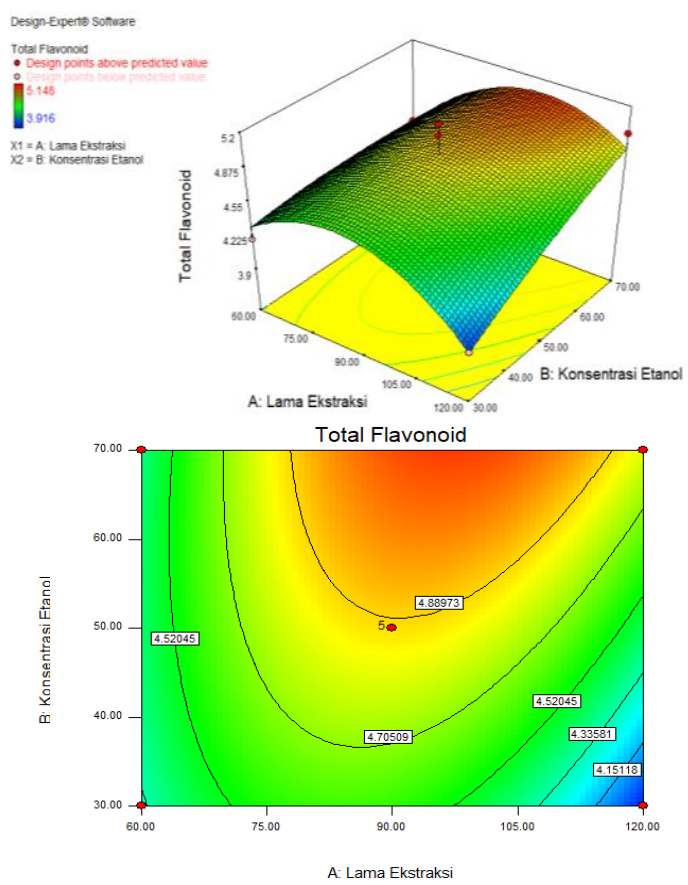

Figure 1 Effect of extraction time and ethanol concentration on total flavonoids of melinjo peel extract

Tabel 1: Response of flavonoid, water content, and yield

\begin{tabular}{|c|c|c|c|c|c|c|c|}
\hline \multirow{2}{*}{ No } & \multicolumn{2}{|c|}{ Variable Code } & \multicolumn{2}{|c|}{ Variable Initial } & \multicolumn{2}{c|}{ Response } \\
\cline { 2 - 8 } & $\mathrm{X} 1$ & $\mathrm{X} 2$ & $\begin{array}{c}\text { Extraction } \\
\text { time Minutes) }\end{array}$ & $\begin{array}{c}\text { Etanol } \\
\text { concentration (\%) }\end{array}$ & $\begin{array}{c}\text { Total Flavonoid } \\
\text { (mg QE/ g exstract) }\end{array}$ & $\begin{array}{c}\text { Water } \\
\text { content (\%) }\end{array}$ & Yield (\%) \\
\hline 1 & -1 & -1 & 60.00 & 30.00 & 4.201 & 6.192 & 33.129 \\
\hline 2 & 1 & -1 & 120.00 & 30.00 & 3.963 & 4.610 & 31.011 \\
\hline 3 & -1 & 1 & 60.00 & 70.00 & 4.412 & 6.136 & 31.535 \\
\hline 4 & 1 & 1 & 120.00 & 70.00 & 4.950 & 4.415 & 30.970 \\
\hline 5 & -1.414 & 0 & 47.58 & 50.00 & 4.034 & 6.286 & 30.683 \\
\hline 6 & 1.414 & 0 & 132.42 & 50.00 & 3.916 & 4.304 & 30.027 \\
\hline 7 & 0 & -1.414 & 90.00 & 21.72 & 4.530 & 5.252 & 35.531 \\
\hline 8 & 0 & 1.414 & 90.00 & 78.28 & 4.981 & 5.812 & 32.421 \\
\hline 9 & 0 & 0 & 90.00 & 50.00 & 5.052 & 6.091 & 34.857 \\
\hline 10 & 0 & 0 & 90.00 & 50.00 & 5.148 & 6.259 & 34.116 \\
\hline 11 & 0 & 0 & 90.00 & 50.00 & 4.746 & 5.540 & 34.982 \\
\hline 12 & 0 & 0 & 90.00 & 50.00 & 4.837 & 5.516 & 35.131 \\
\hline 13 & 0 & 0 & 90.00 & 50.00 & 4.600 & 5.879 & 35.341 \\
\hline
\end{tabular}


Based on Figure 1, the total flavonoids increased with extraction time, but after optimal conditions, they decreased. This condition is because the solution becomes saturated after the equilibrium condition or the extracted flavonoids have been exhausted. $\mathrm{Wu}$ et al. [20] stated that the extraction process lasted until the equilibrium condition. If the time is too short, the analyte dissolution is not perfect, while if it is too long, the solution becomes saturated so that the extraction process is not effective [23].

In this study, the ratio of the material-solvent is 1:30. The large volume of solvent causes the possibility of the analyte extracted to be greater than the saturated solution. The higher the ethanol solvent ratio, the greater the pressure on the material resulting in a greater plasmolysis process so that a lot of cell fluid comes out [24]. When all flavonoids in the sample had dissolved, the adding extraction time did not affect the extract. Besides, the decrease in flavonoids due to instability and damage to the compound was higher. In this study, flavonoid damage was triggered by light exposure during extraction. According to Peretta [25], flavonoids are relatively stable and resistant to heat and oxygen but are damaged by light. The longer the extraction, the exposure to light can damage the flavonoids in the extract.

Total flavonoids increased with higher ethanol concentration [26]. Ethanol is polar and soluble in water. The hydroxyl group in ethanol can partition into hydrogen and water bonds, thus making it liquid and more difficult to evaporate than other organic compounds with the same molecular mass [27]. Flavonoids and their glycosides are polar and can be extracted efficiently with ethanol solvent, where the tensile strength depends on the concentration. The higher the alcohol concentration, the greater the pulling power of the compound [16].

\subsection{Water Content}

Based on the water content response analysis, the following is a polynomial regression equation.

$\mathrm{Y} 2=7.68161-0.025442 \mathrm{X} 1+3.38100 \mathrm{E}-003 \mathrm{X} 2 \ldots$ (4)

Where: $\mathrm{Y} 2=$ Water content; $\mathrm{A} ; \mathrm{X} 1=$ Extraction time; $\mathrm{B} ; \mathrm{X} 2=$ Ethanol concentration

The effect of extraction time and ethanol concentration on the water content is shown in Figure 2.

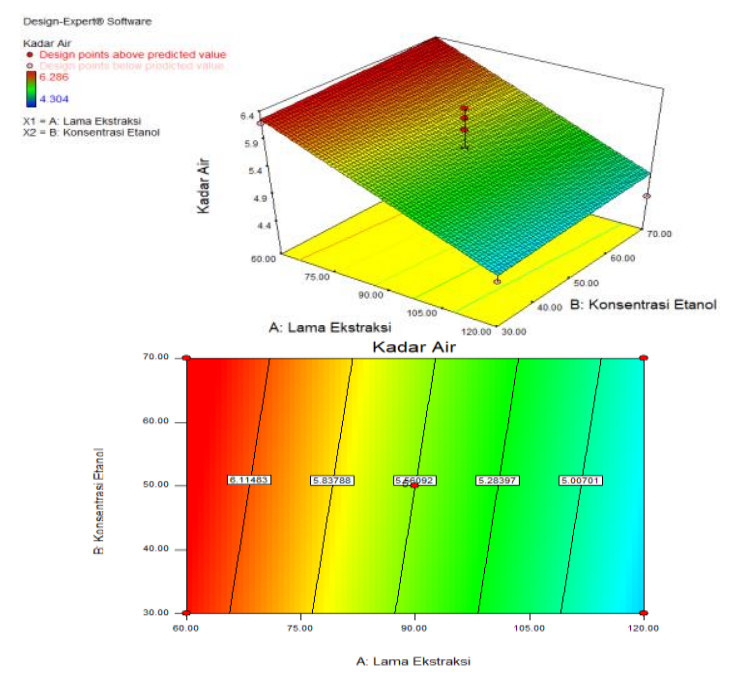

Figure 2 Effect of extraction time and ethanol concentration on moisture content of melinjo peel extract

Figure 2 shows the water content decreases with increasing extraction time. The longer the extraction, the more solvent is absorbed into the sample [28]. The amount of water evaporated during extraction increases as the extraction time increases [29]. The ethanol concentration had no significant effect on the water content. The results of this research are different from the statement of Rohaeni et al. [30], that the higher the solvent concentration of ethanol, the lower the water content. Ethanol attracts water, so the higher the concentration, the greater the attraction. In addition, high concentrations of ethanol cause easier evaporation. This difference is thought to be due to almost the same volume of concentrated filtrate from the evaporation of each sample. The vacuum drying process has an effect because of changing the sample from liquid to solid (powder); enough water is evaporated so that the water content in the sample does not give a significant difference.

\subsection{Yield}

Based on the water content response analysis, the following is a polynomial regression equation.

$\mathrm{Y} 3=15.488554+0.43085 \mathrm{X} 1+0.049246 \mathrm{X} 2+$ $6.47083 \mathrm{E}-004 \mathrm{X} 1 * \mathrm{X} 2-2.65696 \mathrm{E}-003 \mathrm{X} 1^{2}-1.45191 \mathrm{E}-$ 003X2.

Where: Y3 = Yield; A; X1 = Extraction time; $\mathrm{B} ; \mathrm{X} 2$ = Ethanol concentration 
The effect of the extraction time factor and ethanol concentration on the yield is shown in Figure 3.

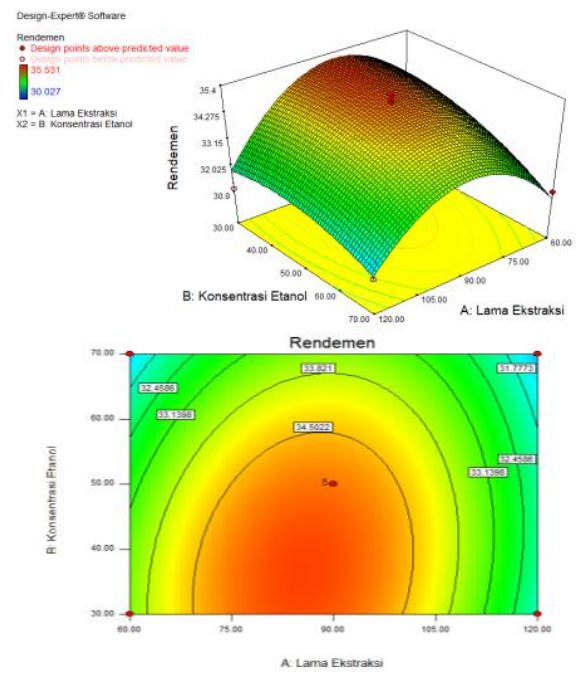

Figure 3 Effect of extraction time and ethanol concentration on yield of melinjo peel extract

Figure 3 shows the yield increases with the addition of extraction time, but it decreases after reaching a certain time. The longer the contact between material and solvent, the better penetration of solvent into the material cell so that more compounds diffuse out of the cell [31]. Extraction is limited to an equilibrium state, where the rate of solute moves to solvent is the same as the rate the solute moves from solvent [32]. The yield decreased after the equilibrium time is due to the ability to take compounds from the material by the solvent reduced, while there is damage to compounds due to prolonged heating [33].

The yield tends to decrease as the solvent concentration increases. The larger the ethanol fraction, the higher the evaporation because the boiling point of ethanol is lower than water [34]. The volatile nature of ethanol and its lower specific gravity than water affect the weight of the extract [35].

\subsection{Model Optimal Verification}

The model verification results (Table 3) at an extraction time of 95.11 minutes and ethanol concentration of 70.00 , producing a total of flavonoid 5,255 (mg QE/g), water content $5.766 \%$, yield $33.657 \%$. The deviation of $0.55 \%$ to $4.63 \%$ is less than $5 \%$, so the model is declared valid. Harmita [36] stated that the measurement deviation of less than or equal to $5 \%$ was declared valid. The slight deviation indicates the verification results meet the model predictions.
The optimal solution based on Design Expert 7.1.5 was obtained at an extraction time of 95.11 minutes and ethanol concentration of $70 \%$, producing a total of flavonoid $5.07251(\mathrm{mg} \mathrm{QE} / \mathrm{g})$, water content $5.4985405 \%$, yield $33.4704 \%$, and accuracy (desirability) is 0.877 . According to Nurmiah et al [37], the desirability value shows the program's ability to fulfill the wishes based on the criteria. The desirability value close to 1 indicates that the model achieves the optimization goal more perfectly.

Table 3. Comparison of model predictions and verification of optimal condition.

\begin{tabular}{|l|c|c|c|c|c|}
\hline & $\begin{array}{c}\text { Lowest } \\
\text { Prediction }\end{array}$ & Prediction & $\begin{array}{c}\text { Higest } \\
\text { Predic } \\
\text { tion }\end{array}$ & $\begin{array}{c}\text { Verification } \\
\text { Result }\end{array}$ & $\begin{array}{c}\text { Devi- } \\
\text { ation } \\
(\%)\end{array}$ \\
\hline $\begin{array}{l}\text { Total } \\
\text { Flavonoid } \\
\text { (mg QE/g) }\end{array}$ & $4 ., 55$ & 5.07251 & 5.59 & 5.255 & 3.47 \\
\hline $\begin{array}{l}\text { Water } \\
\text { content } \\
(\%)\end{array}$ & 4.59 & 5.49854 & 6.41 & 5.766 & 4.63 \\
\hline Yield (\%) & 31.81 & 33.4704 & 35.13 & 33.657 & 0.55 \\
\hline
\end{tabular}

The predicted results of the optimal model solution at extraction time of 95.11 minutes and ethanol concentration of $70 \%$, the verification and deviations after being tested in the laboratory with three replications.

\section{CONCLUSION}

The study results showed the optimum extraction time of 95.11 minutes and ethanol concentration of $70 \%$. This optimal condition resulted in predictions of total flavonoids $5.07251 \mathrm{mg} \mathrm{QE} / \mathrm{g}$, water content $5.49854 \%$, and yield of $33.4704 \%$. The verification results showed that the flavonoid deviation was $3.47 \%$, water content was $4.63 \%$, and yield was $0.55 \%$, which means the model can correctly predict the response. In the future, it is necessary to study the effect of stirring, evaporation time, particle size, drying time on response.

\section{REFERENCES}

[1] H. Sunarto, Budidaya melinjo dan usaha produksi emping: cetakan 13, Kanisius, Yogyakarta, 2008.

[2] S. Wulandari, Subandi, Muntholib, Inhibisi Xantin Oksidase oleh Ekstrak Etanol Kulit Melinjo (Gnetum gnemon) Relatif terhadap Allopurinol, Jurnal Online Universitas Negeri Malang, vol. 1, no. 1, 2012, pp. 1-9.

[3] Muhtadi, A. Suhendi, N. W., E.M. Sutrisna, Potensi Daun salam (syzigium polyanthum walp.) dan biji jinten hitam (nigella sativa linn) 
sebagai kandidat obat herbal terstandar asam urat, Pharmacon, vol. 13, no. 1, 2012, pp. 3036.

[4] S.M.N. Azmi, P. Jamal, A. Amid, Xanthine oxidase inhibitory activity from potential Malaysian medicinal plant as remedies for gout, International Food Research Journal, vol. 19, no. 1, 2012, pp. 159-165.

[5] A. Yumita, A.G. Suganda, E.Y. Sukandar, Xanthine oxidase inhibitory activity of some Indonesian medicinal plants and active fraction of selected plants, International Journal of Pharmacy and Pharmaceutical Sciences, vol. 5, no. SUPPL. 2, 2013, pp. 293 296.

[6] I.R. Alsultanee, M.J. Ewadh, M.F. Mohammed, Novel natural anti gout medication extract from momdica charantia, Journal of Natural Science Research, vol. 4, no. 17, 2014, pp. 16-24.

[7] T.D. Nguyen, P.T. Thuong, I.H. Hwang, T.K.H. Hoang, M.K. Nguyen, H.A. Nguyen, M.K. Na, Anti-hyperuricemic, antiinflammatory and analgesic effects of siegesbeckia orientalis 1 . resulting from the fraction with high phenolic content, BMC Complementary and Alternative Medicine, vol. 17, no. 1, 2017, pp. 1-9. DOI: https://doi.org/10.1186/s12906-017-1698-z

[8] H.S.M.A. El-Rahman, N.A.M. Abd-ELHak, Xanthine Oxidase Inhibitory Activity and Antigout of Celery Leek Parsley and Molokhia, Advances in Biochemistry, vol. 3, no. 4, 2015, pp. 40-50. DOI: https://doi.org/10.11648/j.ab.20150304.11

[9] O. Sperling, A. De Vries, J.B. Wyngaarden, Purine metabolism in man: enzymes and metabolic pathways, Springer, Boston, 1974.

[10] C.A. Puspita, E.Z. Akhmad, Husnawati, Efektivitas Kulit melinjo (gnetum gnemon) sebagai penurun kadar asam urat pada tikus putih (rattus norvegicus) hiperurisemia, IPB University.

[11] T.M. Siregar, M. Cornelia, T. Ermiziar, S. Raskita, The Study of Antioxidant Activity, Carotenoid and Vitamin C Content of Melinjo Peels (Gnetum gnemon L), Perhimpunan Ahli Teknologi Pangan Indonesia (PATPI). ISBN 978-979-99570-5-4

[12] H. Sa'adah, H. Nurhasnawati, Perbandingan Pelarrut etanol dan air pada pembuatan ekstrak umbi bawang tiwai (eleutherine americana merr) dengan metode maserasi, Jurnal Ilmiah Manuntung, vol. 1, no. 2, 2017, p. 149.

[13] E. Afifah, Tim Lentera, Khasiat dan manfaat temulawak rimpang penyembuh aneka penyakit, Agromedia Pustaka, Jakarta, 2003.

[14] I. Rosidah, Z. Zainuddin, R. Mufidah, H. Bahua, M. Saprudin, Optimasi kondisi ekstraksi senyawa total fenolik buah labu siam (sechium edule (jacq.) sw.) menggunakan response surface methodology, Media Penelitian dan Pengembangan Kesehatan, vol. 27, no. 2, 2017, pp. 79-88. DOI: https://doi.org/10.22435/mpk.v27i2.5706.7988

[15] S. Badal, D. Rupika, Pharmacognosy: fundamentals, applications and strategies, Elsevier, London, 2017.

[16] A. Fahr, Voigt's pharmaceutical technology, John Wiley \& Sons Ltd, New Jersey, 2017.

[17] D.C. Montgomery, Design and analysis of experiments: ninth edition, John Wiley \& Sons Ltd, New Jersey, 2017.

[18] N.F. Azahar, S.S.A. Gani, N.F. Mohd Mokhtar, Optimization of phenolics and flavonoids extraction conditions of Curcuma Zedoaria leaves using response surface methodology, Chemistry Central Journal, vol. 11, no. 1, 2017, pp. 1-10. DOI: https://doi.org/10.1186/s13065-017-0324-y

[19] Y. Liu, H. Wang, X. Cai, Optimization of the extraction of total flavonoids from Scutellaria baicalensis Georgi using the response surface methodology, Journal of Food Science and Technology, vol. 52, no. 4, 2014, pp. 2336-43. DOI: http://dx.doi.org/10.1007/s13197-0141275-0

[20] L. Wu, J. Hu, W. Xiong, X. Li, G. Wang, L. Dai, Y. Bae, C. Si, Optimization of the extraction process for flavonoids from basil (Ocimum basilicum) using response surface methodology, Journal of Bioresources and Bioproducts, vol. 1, no. 4, 2016, pp. 177-185. DOI: $10.21967 /$ jbb.v1i4.61

[21] A.N. Cahyanta, Penetapan kadar flavonoid total ekstrak daun pare metode kompleks kolorimetri dengan pengukuran absorbansi secara spektrofotometri, Electronic Journal Politeknik Harapan Bersama Tegal, vol. 5, 2016, pp. 58-61.

[22] Badan Standarisasi Nasional (BSN), Analisa Kadar Air (SNI 01-2891-1992). BSN, Jakarta.

[23] N.C.R. Yuswi, Ekstraksi antioksidan bawang dayak (eleutherine palmifolia) dengan metode ultrasonic bath (kajian jenis pelarut dan lama ekstraksi, Jurnal Pangan dan Agroindustri, vol. 5, no. 1, 2017, pp. 71-79.

[24] H. Handayani, F.H. Sriherfyna, Yunianta, Ekstraksi Antioksidan daun sirsak metode ultrasonic bath (kajian rasio bahan: pelarut dan lama ekstraksi), Jurnal Pangan dan 
Agroindustri, vol. 4, no. 1, 2016, pp. 262-272.

[25] L. Peretta, Makanan untuk otak, Erlangga, Jakarta, 2017.

[26] Q.D. Do, A.E. Angkawijaya, P.L. TranNguyen, L.H. Huynh, F.E. Soetaredjo, S. Ismadji, Y.H. Ju, Effect of extraction solvent on total phenol content, total flavonoid content, and antioxidant activity of Limnophila aromatica, Journal of Food and Drug Analysis, vol. 22, no. 3, 2014, pp. 296-302. DOI: https://doi.org/10.1016/j.jfda.2013.11.001

[27] E. Nihiyati, peningkatan produksi dan kadar kurkumin temulawak, UB Press, Malang, 2016.

[28] D. Desmawarni, F.H. Hamzah, Variasi suhu dan waktu ekstraksi terhadap kualitas pektin dari kulit pisang tanduk, JOM Faperta UR, vol. 4, no. 1, 2017, pp. 1-15.

[29] I. Cikita, I.H. Hasibuan, R. Hasibuan, Pemanfaatan flavonoid ekstrak daun katuk (Sauropus androgynus (L) merr) sebagai antioksidan pada minyak kelapa, Jurnal Teknik Kimia USU, vol. 5, no. 1, 2016, p. 46.

[30] N.S. Rohaeni, Hervelly, I.S. Nurminabari, Kajian Konsentrasi pelarut terhadap ekstrak pigmen dari sabut kelapa (cocos nucifera 1) sebagai pewarna alami, Jurnal Teknologi Pangan Universitas Pasundan, 2015.

[31] P. Mardina, E. Astarina, S. Aquarista, Pengaruh kecepatan putar pengaduk dan waktu operasi pada ekstraksi tannin dari mahkota dewa, Jurnal Kimia, vol. 5, no. 2, 2011, pp. 125-132.

DOI: https://doi.org/10.24843/JCHEM

[32] S. Zullaikah, C. Clarizka, D. Fulanah, L. Fitri, Y. Refit, Subcritical water extraction of essential oils from indonesia basil (kemangi) leaf: effects of temperature and extraction time on yield and product composition, in Prosiding Seminar Nasional Teknik Kimia "Kejuangan, 2015, pp. 1-7.

[33] D. Yulianti, B. Susilo, R. Yulianingsih, Pengaruh lama ekstraksi dan konsentrasi pelarut etanol terhadap sifat fisika-kimia ekstrak daun stevia (stevia rebaudiana bertoni m.) dengan metode microwave assisted extraction (MAE), Jurnal Bioproses Komoditas Tropis, vol. 2, no. 1, 2014, pp. 3541.

[34] D. Agustin, Ismiyati, Pengaruh konsentrasi pelarut pada proses ekstraksi antosianin dari bunga sepatu, Konversi, vol. 4, no. 2, 2015, pp. 9-16.

[35] A. Ghasemzadeh, A. Baghdadi, H.Z.E. Jaafar, M.K. Swamy, P.E. Megat Wahab, Optimization of flavonoid extraction from red and brown rice bran and evaluation of the antioxidant properties, Molecules, vol. 23, no. 8, 2018, pp. 1-18. DOI: https://doi.org/10.3390/molecules23081863

[36] Harmita, Petunjuk pelaksanaan validasi metode dan cara perhitungannya, Jurnal Ilmu Kefarmasian, vol. 1, no. 3, 2004, pp. 117-135. DOI: http://dx.doi.org/10.7454/psr.v1i3.3375

[37] S. Nurmiah, R. Syarief, R. Peranginangin, B. Nurtama, Aplikasi Response Surface Methodology Pada Optimalisasi Kondisi Proses Pengolahan Alkali Treated Cottonii (ATC), Jurnal Pascapanen dan Bioteknologi Kelautan dan Perikanan, vol. 8, no. 1, 2013, pp. 9-22. DOI: http://dx.doi.org/10.15578/jpbkp.v8i1.49 